player he was deadly accurate and he had, for his opponent, a most annoying habit of holing short shots from the edge of the green. To this journal Grimsdale contributed papers and abstracts of current Italian literature. He also read Spanish.

During the London air raids his house was demolished and we fèar that his death must be largely attributed to the effects of the war. What it must have meant to him to lose the records of nearly fifty years of work as well as his furniture and fine collection of china only those who knew him can appreciate.

Mr. Grimsdale married Miss Mabel Todd in 1903. There were no children of the marriage. The ophthalmic fraternity will wish to express their sincere sympathy with his widow in her bereavement.

\title{
EMIL DE GROSZ
}

DE GRosz, who died at Budapest recently at the age of 77 years, was of the third generation of a family of ophthalmologists. His grandfather, a doctor of philosophy of Budapest University and a doctor of medicine of Vienna University, founded and maintained at his own expense an eye hospital in one of the provincial towns of Hungary. He was succeeded there by his son who became chief medical officer of the city, Nagyvarad, now a Rumanian possession. The grandson, Emil de Grosz, is the subject of this notice.

He was one of the best known medical men in Europe. He was a member of the Ophthalmological Society of the United Kingdom, and of the Ophthalmologicat Societies of Germany, France and Belgium. He was an honorary.member of the Ophthalmic Section of the Royal Society of Medicine and of the Ophthalmological Societies of Egypt, Brazil, Spain and Italy. He was also an honorary fellow of the American College of Surgeons and an honorary member of the American Academy of Ophthalmology and Otolaryngology. $\mathrm{He}$ was entitled to wear numerous decorations, both national and foreign.

He became professor and director of the No. 1 Ophthalmological Clinic at Budapest in 1905. In 1909 he was chief secretary of the XVI International Medical Congress held at Budapest, when some of us, who had already made his acquaintance, became warmly attached to him. In 1914 he became for a period Dean of the Medical Faculty at Budapest. In 1929 the XIII -International Congress of Ophthalmology instituted the International Organization against Trachoma of which de Grosz became the first President; the first meeting of the Organization was held at Geneva in the following year, and subsequently annual meetings were held during his five years' tenure of the office.

During his long professional life de Grosz published many original articles, the most important of which are those on trachoma and on 
glaucoma. His numerous visits to London and to other European capitals were for him a pleasure and a relaxation, and during them he made many sincere friends.

His surviving son, Dr. Geza de Takats, whose surname is that of his mother, is a general surgeon at Chicago; there is an important article by him on the surgical approach to hypertension in the Journal of the American Medical Association for February 14, last.

\section{DR, CASEY WOOD}

THE death of Casey Albert Wood on January 26, 1942, at the great age of 85 is announced. He was born in Canada in 1856 and took his M.D. from Bishop's College, Montreal, in 1877. In those far off days he was one of Osler's clinical clerks at McGill, and the friendship between them lasted until Osler's death.

Casey Wood started practice in Montreal as a physician, but he was always interested in ophthalmology and in 1886 he left Montreal and spent some years in post graduate work in England and on the Continent. In 1890 he settled in Chicago and rapidly developed a large ophthalmic practice. He was professor of ophthalmology at Northwestern University in 1900, and from 1904-1925 at the University of Illinois. Casey Wood was a prolific author. Besides a great many papers of clinical interest he was an editor of the American Encyclopaedia of Ophthalmology and also of a system of ophthalmic operations. But probably his best known work - was done in comparative ophthalmology; the fundus oculi of Birds came out in 1917 and later he issued a large quarto "introduction to the literature of vertebrate zoology," a copy of which, a present from the author, is one of the writer's treasured possessions. $\mathrm{He}$ was a generous benefactor to McGill, and the "introduction" referred to * above, is practically a list of all the works on this subject there, many of them donated by himself.

After retirement from active practice Casey Wood spent much of his time abroad and worked in Rome at the Vatican Library. His scholarly translation of Benevenutus Grassus on the eye, and the memorandum book of Jesus Hali are well known. His knowledge of the history of ophthalmology was most extensive, while the Blacker Library of Zoology and the' Emma Shearer Wood Library of Ornithology at McGill are a lasting memorial of his generosity and ability. His ophthalmological collections also went to McGill Medical Library, and he was the donor of some valuable oriental manuscrips to the Osler Library. McGill gave him the degree of . M.D. in 1905 and LL.D. in 1922.

An obituary notice of Casey Wood appeared in the March number of the Canadian' Medical Association Journal and to it we are indebted for most of the facts recorded here. At the same time we may state that the writer has been acquainted with Casey Wood for certainly the past 15 years, and has been indebted to him for much friendly correspondence, reprints and books. 